\title{
SITUATIONS REFFERING TO THE ORGANIZATION, CLASSIFICATION AND MANAGEMENT OF ECONOMIC DATA
}

\author{
Măriuța ȘERBAN* \\ E-mail: t_mariuta@yahoo.com \\ Lăcrămioara-Rodica HURLOIU* \\ E-mail: hlacra@yahoo.com \\ Raluca-Mariana ŞTEFAN* \\ E-mail: ralucastefan77@yahoo.com \\ Iulian-Ioan HURLOIU* \\ E-mail: iulian.hurloiu@gmail.com \\ "Spiru Haret University, Bucharest
}

\begin{abstract}
An efficient information system provides relevant, accurate, reliable and timely information to users. This information is stored as data in files, which must be arranged and maintained so that users can easily obtain the information they need.

Data management is a very important part of the economic organizational information system because it influences the speed with which data can be obtained and, therefore, the decision may be taken. There are times when speed decision is vital to the economic organization. Such information systems, resource data type must be organized and structured in a logical way that allows easy access, efficient processing, fast data access and effective management.
\end{abstract}

Keywords: data classification, managing data, data access, data management

\section{JEL Classification: $\mathbf{C}_{81}$}

\section{Introduction}

Conceptually, it is stated that a database is an organized collection of data which satisfies the informational demands of an organization.

Simultaneously, in a complementary understanding, a database is the multitude of recordings, sets and specific areas of information which are under the control of a certain setup.

Within the same context we emphasize that a database represents a centralized multitude of data, which aims to improve data processing within systems.

The entity represents an actual or abstract object described through its features. The feature of an object is expressed through an attribute - value relation. As such, the entities can be formalised by multitudes of pairs. 
The data represents at least one model of organizing indivisible information in relation to the represented information. Data can also be found in relation to the processing type, becoming elementary, therefore forming composed data.

At the same time, database management has developed to such an extent that it has become a key component of modern decisional informational systems.

\section{Rational localisation of data security for Database Management Systems (DBMS)}

The formations of database management include informatics systems specialized in storing and processing a considerable volume of data and are used in solving numerous knowledge matters.

Organizing data represents a conceptual alignment, important for developing informatics systems, the level of efficiency of an informatics system being dependent on this. (figure 1.)

Figure no. 1. Basic configurative elements for data organizing

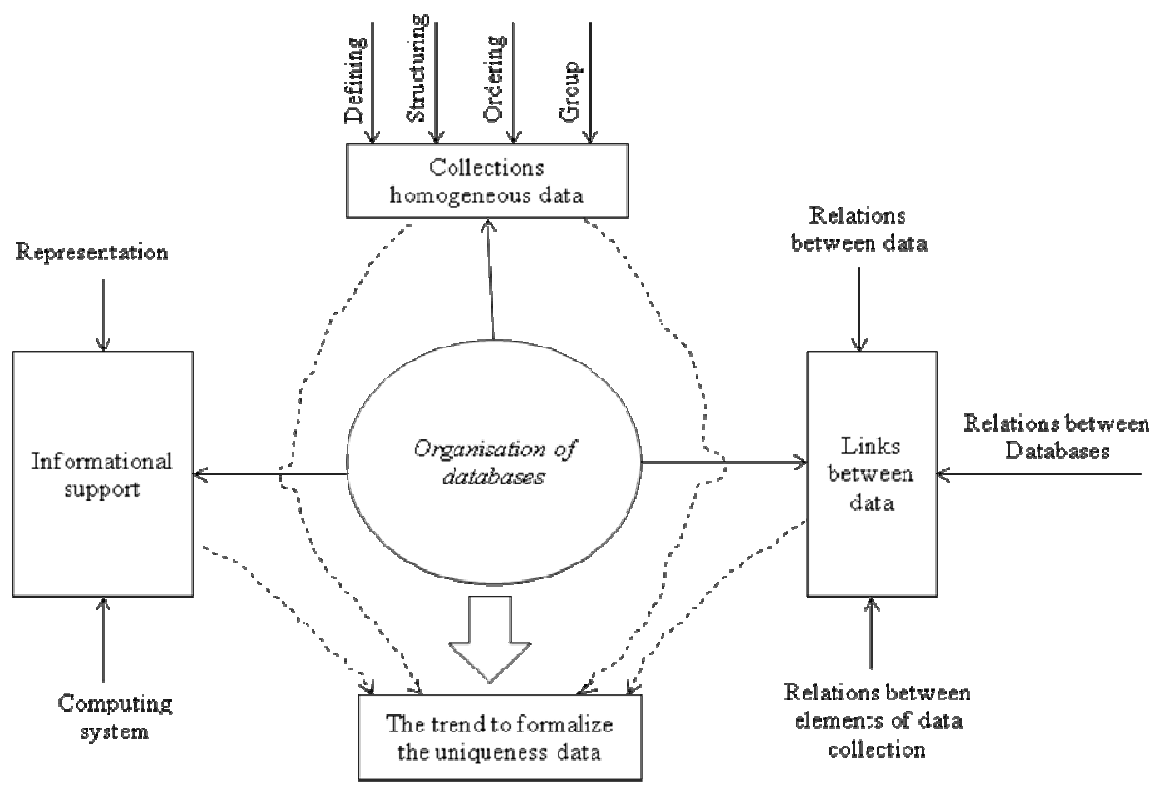

Source: Compiled by the author

The basic concepts which can be found in this domain due to database formalization refer to: 1) entity; 2) attribute and 3) value.

Data security is schematically applied for efficient database operationalization. 
„Data structures are collections of data, having between them a series of connections which lead to a mechanism of selection and identification of components and potential interventions on them" (figure 2).

Figure no. 2. Results of database structures interventions

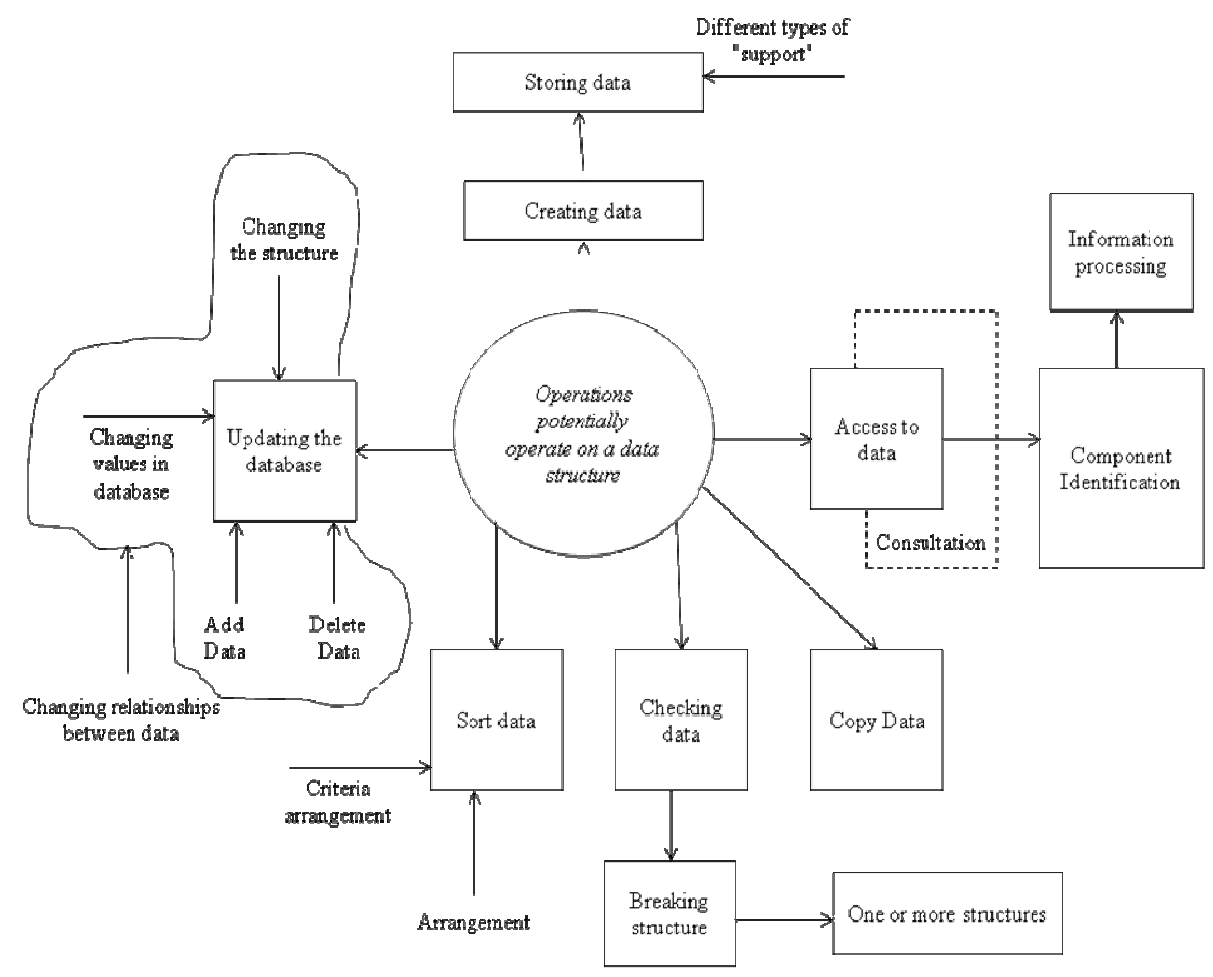

Source: Compiled by the author

The concise context presented above mentions the extremely large variety of database.

The architecture of database mainly includes:

1)the proper database (which registers the data collection);

2) the database management system (an ensemble of programs with the purpose of data maintenance and complex processing);

3) the database dictionary, respectively the meta-database (includes information on data, their structure, semantics description etc.).

The superior conceptual level used for a concise description in this area refers to Database Management Systems (DBMS) (figure 3.). 
Therefore, in an extensive understanding, a Database Management Systems (DBMS) is an ensemble of programs which formalize the interface between a database and its users. (Mihăescu L., 2009)

Figure no. 3. The relational localization of data security for a Database Management Systems (DBMS)

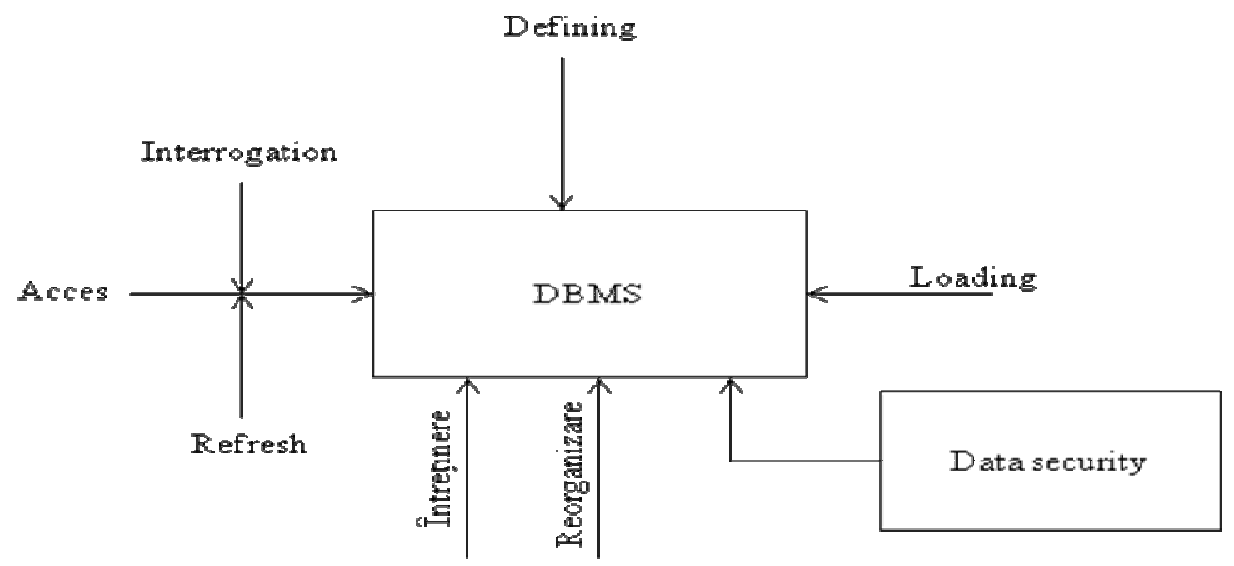

Source: Compiled by the author

Data security proves to be an essential, analytical, concise and practical step in the domain.

By accomplishing the objectives of informatics it implies automatically collecting, verifying, communicating, storing and processing data. This satisfies both the demands and the need for efficient information.

This frame hosts data independence manifestation, recording minimal redundancy of some data usage facilities.

Simultaneously, we assist at increasing the degree of database security and ensuring their shareability.

Presently, informational technologies have a significant influence over data security and determine, globally, effective changes over managerial and productive operationalization means.

\section{The Management of data stored in economic database}

Simultaneously, database management has developed to such an extent that it has become a key component of modern decisional informational systems.

The elements which contribute to this evolution mainly refer to the new modelling techniques and instruments, based on object thinking, the discovery of client-server processing, the reduction of prices for hardware components and software as well, efficient and corporative management of data. 
Product Data Management (PDM) represents the function in an organization, often part of the product's life cycle management concept, which is responsible for creating, managing and publishing product data.

Product data management represents the management of all data which circulates in an organization, needed for being used in developing new products or updating current products. PDM is a system of technical information management for manufacturing enterprises, industrial installations constructions and engineering services. PDM has been known also as Technical Information Management or Product Information Management. PDM represents all the informatic instruments used to manage data for a certain product when the product goes from design to manufacturing, as well as data correlations, so that when modifications are performed in a database, the effects will be reflected in all the others as well.

PDM has been developed for working groups as well as for the entire economical organization, improving communication between groups and forming the bases on which institutions can reorganize their product development processes and can establish initiatives such as concurrent engineering (simultaneous) and collaborative development of products.

By using product data management, an organization can follow the different costs associated with the manufacturing and the launch of the product.

\section{Data organization ranking}

The most significant volume of information can be efficiently used with the help of more modern operationalized means in a secured environment. Practically, the process of automatic data processing through electronic computing systems represents the requirement for the quasi-totality of activity domains where information plays a crucial part no matter the scale.

The above affirmations confirm the fact that a relational database represents a shared collection of data, with logical connections in between, being designed for meeting the informational needs of the users' organizations.

In fact, in the contemporary informational environment, designing and managing a database is done through a multitude of software products which surpasses the multitude of hardware components.

Therefore, in the domain, this paper suggests a new structured approach towards the development of software products, called revolvent life cycle of informational systems. (Lungu I., et al., 1995)

An informational system can be presented as an ensemble of informational flows and circuits combined in a single whole which makes the connection between the decision making - leading system and the operational - executional system, all starting from a data dictionary (figure 4). 
Figure no. 4. The simple configuration of a database

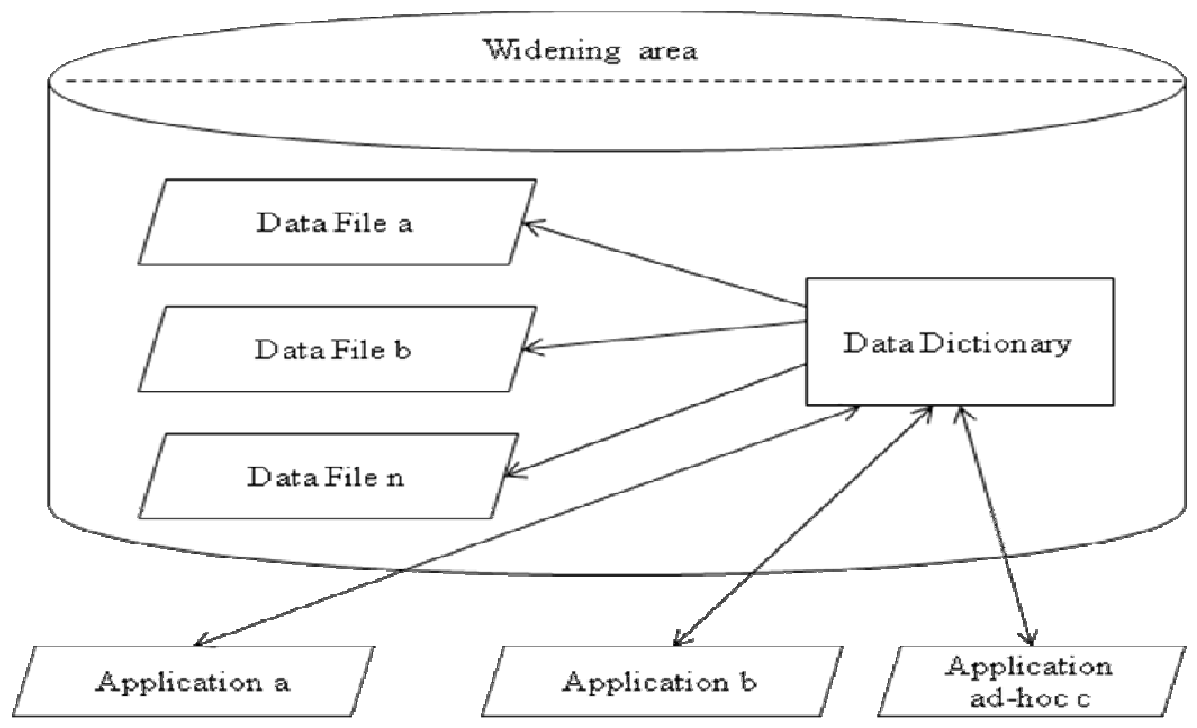

Source: Compiled by the author

On the other hand, solving data organization offers the chance for differentiated intervention, visible and focused on level elements under the incidence of security (Lungu I., et al., 1995) (figure 5).

Figure no. 5. Data organization ranking starting from attributes found in different fields

Attribute 2

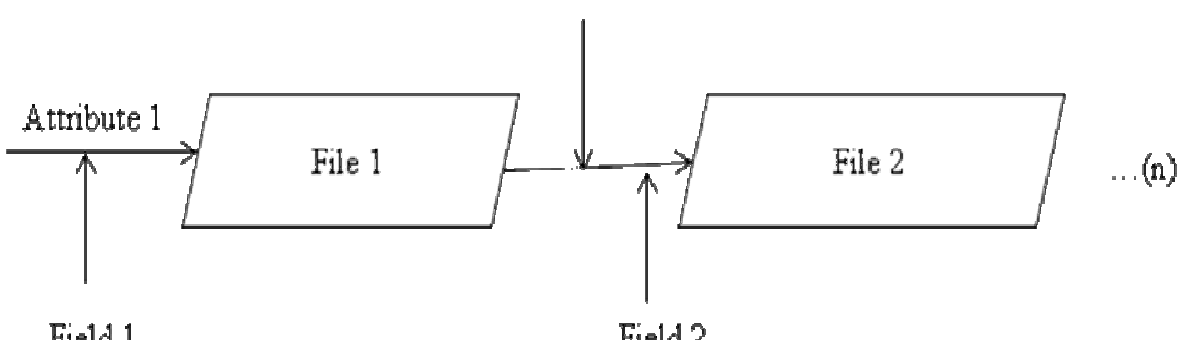

Field 1

Field 2

Source: Compiled by the author

The levels of database organization are the ones which indicate different intensities, differentiated from security actions.

Ensuring data integrity represents the precondition to any security measures.

Through data integrity, data correctness is also maintained.

This is why the database management system offers its users the option to specify restrictions related to the correctness of data inserted into the database. 
The next conditional phase aims to increase protection for the data kept as integrity against intentional or unintentional destruction.

At a bi-directional presumptive level it is identifiable concerning the action area of data protection methods. Contextually, it refers to protection against accidental damages or errors, respectively ensuring complete protection. The latter (reiteration for achieving complete protection) is done in addition to the first iteration.

To the same extent it is also discussed the protection against intentional actions.

It's been observed that, by using multiple computer networks for compiling a large volume of data, it is necessary to achieve multiple versions of protecting existing data.

\section{Conclusions}

The informational methods, techniques, procedures and software instruments are subsumed to the methodological theoretical progression for database security. By extending, we reach the conclusion that the autonomy of the projective sequences/sub-sequences in this domain is relative; therefore, suitability to the database domain is required for ensuring a sustainable security system.

Simultaneously, database management has developed to such an extent that it has become a key component of modern decisional informational systems. Thereby, the usage of product data management offers to an organization the advantage of tracking different costs associated with the manufacturing and the launch of the product.

\section{References}

- Andronie M. (2010), "Economic Process Optimization Deployed By Companies With Complex Activity Production-Trade-Services Using Informatics Systems With Integrated Data Mining Techniques." Annals of Spiru Haret University 1(1): 77-84.

- Burtea E., Hurloiu L., Meruță A. (2012), Managementul societăţii cunoaşterii în context european / Management of the knowledge society in the context of European, in: materialele Conferinţei Economice Naţionale CEN 2012, vol. Echilibre şi dezechilibre ale pieței româneşti în perioada actuală, București: Editura Universitară, p. 190-199.

- Helms R.W. (2002), Product Data Management as enabler for Concurrent Engineering, University Press of Eindhoven University of Technology.

- Hurloiu L., Burtea E., Hurloiu I., Meruță A., Preda B., Şerban M., Ștefan R. (2014), Documentele financiar contabile - Management, control, audit, clasificare şi securitate/Documents financial accounting - Management, control, audit, classification and security, Chiţinău: Centrul editorial al UASM.

- Gherasim Z. (2010), Competitiveness In Organizational Integrated Computer System Project Management. Annals of Spiru Haret University, Economic Series, 1(2), 215-220.

- Jain A.K., Murty M.N., Flynn P.J. (1999), Data clustering: a review. ACM Computing Surveys, 31(3). 
- Lungu I., Bodea C., Bădescu G., Ioniţă C. (1995), Baze de date, Organizare, proiectare şi implementare/ Database, Organization design and implementation, Bucureşti: Editura All.

- Mihăescu L. (2009), Informatizarea sistemului de comunicaţii a firmei/ Informatization system communications company, Sibiu: Editura Universităţii Lucian Blaga.

- Şerban M., Ştefan R.-M., Hurloiu L. (2013), Monitoring and Controlling the Access to Classified Economic Data, Revista Economică - Journal of economic-financial theory and practice, 65(6), p. 216-224. 